\title{
Investigation on Water Retention Properties of Boric Acid Doped Textile Surfaces
}

\author{
F. Akarslan* and Ö. Altinay
}

Süleyman Demirel University, Textile Engineering Department, Isparta, Turkey

\begin{abstract}
During the summer periods, the excellent absorbency and high water retention capacity of textile materials is important to eliminate the disturbing effect of perspiration. In this study, water retention properties of boric acid-doped textile surfaces has been investigated. For this purposes different proportions of boric acid were applied to $100 \%$ cotton fabric by means of impregnation method. Then, water retention was tested according to DIN 53923 standard, as a percentage of the water retention rate. The results were analyzed.
\end{abstract}

DOI: 10.12693/APhysPolA.128.B-405

PACS: 81.05.-t, 81.90. $+\mathrm{c}$

\section{Introduction}

Boron, the fifth element in the periodic table, does not occur in nature in its elemental form. Rather, boron combines with oxygen as a salt or ester of boric acid. There are more than 200 minerals that contain boric oxide, however relatively few of them are of commercial significance. In fact, three minerals represent almost $90 \%$ of the borates used by industry: borax, the sodium borate; ulexite, the sodium-calcium borate; and colemanite, the calcium borate. These minerals are extracted in California and Turkey, and to a lesser extent in Argentina, Bolivia, Chile, Peru, and China. China and Russia also have some commercial production from magnesium borates and calcium borosilicates. Presently these deposits furnish nearly all of the world's borate supply [1].

Boron compounds have been used for thousands of years [2]. Turkey is the world largest source of the boron. $63 \%$ of the world's total reserves are located in Turkey. However, the advantages of such location can not be fully evaluated. Boron consumption in Turkey is at very low level, of around 1-2\% of world's consumption. As of 2000 , Turkey's boron was consumed in production of steel $27 \%$, glass $12 \%$ and fiberglass $38 \%$, ceramic $12 \%$, detergents $5 \%$, and $6 \%$ in other sectors of chemistry [3].

During the summer periods, the excellent absorbency and high water retention capacity of textile materials is important to eliminate the disturbing effect of perspiration. In this study, water retention properties of boric acid applied to the textile surface were investigated.

\subsection{Boric acid}

The name boric acid is usually associated with orthoboric acid, which is the only commercially important form of boric acid and is found in nature as the mineral sassolite. Three crystalline modifications of metaboric acid also exist. All these forms of boric acid can

*corresponding author; e-mail: afeyza@gmail.com be regarded as hydrates of boric oxide and formulated as $\mathrm{B}_{2} \mathrm{O}_{3} \cdot 3 \mathrm{H}_{2} \mathrm{O}$ for orthoboric acid and $\mathrm{B}_{2} \mathrm{O}_{3} \cdot \mathrm{H}_{2} \mathrm{O}$ for metaboric acid.

\section{Materials and methods}

In this study, $100 \%$ cotton, raw knitted fabrics (Ne 30/1) was used. The prepared samples had the dimensions of $10 \times 10 \mathrm{~cm}^{2}$. Boric acid was provided by Eti Mine Works General Directorate. Before the study, fabric samples were conditioned for 24 hours under laboratory conditions. $10 \%, 20 \%$ and $30 \%$ solutions of boric acid were applied to the fabric samples by impregnation method under pressure of 2 bar. After application of boric acid by this method, fabric samples were fixed. Fixed fabrics were tested for water absorbency according to DIN 53923 standard.

\section{Results and discussions}

The results of water absorbency tests of boric acidtreated fabric are given in Table. According to this table, water retention increases with the increase of boric acid ratio. This growth is shown in Fig. 1.

TABLE

Hydrophility of boric acid-treated fabric.

\begin{tabular}{c|c|c|c|c}
\hline \hline $\begin{array}{c}\text { Boric } \\
\text { acid } \\
{[\%]}\end{array}$ & $\begin{array}{c}\text { Dry } \\
\text { weight } \\
{[\mathrm{g}]}\end{array}$ & $\begin{array}{c}\text { Weight } \\
\text { after } \\
\text { treatment }[\mathrm{g}]\end{array}$ & $\begin{array}{c}\text { Weight } \\
\text { after } \\
\text { fixing }[\mathrm{g}]\end{array}$ & $\begin{array}{c}\text { Weight } \\
\text { after } \\
\text { testing }[\mathrm{g}]\end{array}$ \\
\hline $\begin{array}{c}\text { reference } \\
10\end{array}$ & 20.065 & - & - & 33.185 \\
20 & 22.15 & 34.41 & 22.51 & 51.461 \\
30 & 22.91 & 38.21 & 22.2 & 53.002 \\
& & & 23.3 & 59.864
\end{tabular}

\section{Conclusions}

Turkey, which is the country with the largest reserves of boron, is capable of achieving market dominance and 


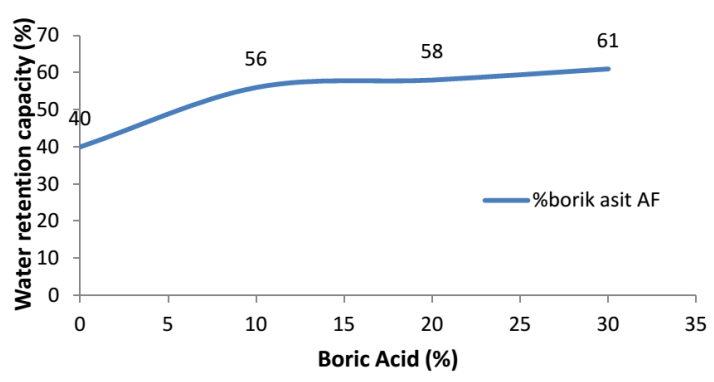

Fig. 1. Water retention capacity as function of the amount of boric acid. the maximum benefit from exports. Turkey may become the market leader in boron high-tech production and selling high-tech end-products.

\section{References}

[1] D. Schubert, Kirk-Othmer Encyclopedia of Chemical Technology, vol. 4, John Wiley \& Sons, 2000, p. 241.

[2] R.G. Holdich, I.W. Cumming, S .Pernı, Chem. Eng. Res. Des. 84, 60 (2006).

[3] V.F. Traven, T.A. Chibisova, A.V. Manaev, Dyes Pigments 58, 41 (2003). 